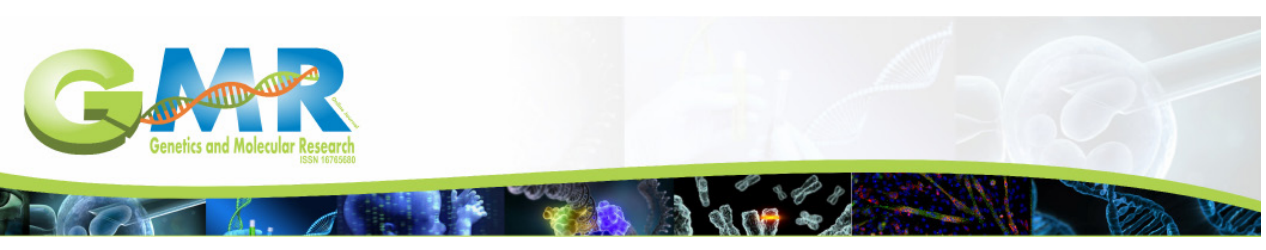

\title{
Association between the MTHFR C677T gene polymorphism and essential hypertension in South West Cameroon
}

\author{
S.M. Ghogomu ${ }^{1}$, N.E. Ngolle ${ }^{1}$, R.N. Mouliom ${ }^{2}$ and B.F. Asa ${ }^{1}$ \\ ${ }^{1}$ Molecular and Cell Biology Laboratory, \\ Department of Biochemistry and Molecular Biology, Faculty of Science, \\ University of Buea, Cameroon \\ ${ }^{2}$ Diabetes and Hypertension Clinic, Regional Hospital, Buea, Cameroon \\ Corresponding author: S.M. Ghogomu \\ E-mail: stephen.ghogomu@ubuea.cm \\ Genet. Mol. Res. 15 (1): gmr.15017462 \\ Received August 17, 2015 \\ Accepted November 13, 2015 \\ Published March 28, 2016 \\ DOI http://dx.doi.org/10.4238/gmr.15017462
}

ABSTRACT. The association of the methylenetetrahydrofolate reductase (MTHFR) C677T gene polymorphism and essential hypertension has been reported but with controversial results in diverse populations in Asia and Europe, thereby suggesting a dependency on ethnicity. The aim of this study was to investigate the association between the MTHFR C677T polymorphism and essential hypertension in a Cameroonian population (Bantu ethnic group) of the South West Region. Analysis of anthropometric and biochemical data in hypertensive and normotensive subjects revealed that age, systolic blood pressure, diastolic blood pressure, lowdensity lipoprotein cholesterol, serum total cholesterol, and triglycerides are independent risk factors for essential hypertension. Substitution of thymine for cytosine at position 667 of the MTHFR gene was determined by polymerase chain reaction-restriction fragment length polymorphism. Genotype frequencies were found to be $7.3 \% \mathrm{CC}, 58.5 \% \mathrm{CT}$, and $34.1 \%$ TT for hypertensive subjects compared to $90.0 \%$ CC, $10.0 \%$ CT, and $0.0 \%$ TT for normotensives. Allele frequencies were obtained as $36.6 \%$ 
$\mathrm{C}$ and $63.4 \% \mathrm{~T}$ for hypertensive subjects and $95.0 \% \mathrm{C}$ and $5.0 \% \mathrm{~T}$ for normotensive subjects. These results reveal that the $\mathrm{T}$ allele predisposes individuals to hypertension. Therefore, there is an association between variants of the MTHFR gene and hypertension in Cameroonian patients from the South West region.

Key words: Hypertension; Risk factors; MTHFR; Genetic polymorphism

\section{INTRODUCTION}

Traditionally in Africa, communicable diseases account for the greatest burden of morbidity and mortality (Lopez et al., 2006). This burden is quickly shifting towards chronic non-communicable diseases and, by extension, cardiovascular diseases. This phenomenon constitutes what is known as a "double burden of disease" (Bygbjerg, 2012). While hypertension was almost non-existent in African societies in the first half of the twentieth century, estimates now show that in some regions in Africa more than $40 \%$ of adults have hypertension (Addo et al., 2007). There were approximately 80 million adults with hypertension in sub-Saharan Africa in 2000 and projections based on current epidemiological data suggest that this figure will rise to 150 million by 2025 (Walker et al., 2000). Complications of hypertension include neurological problems, renal impairment, hypertensive retinopathy (Tchoumi and Butera, 2013), stroke, and heart failure (Whelton et al., 2002; Mensah, 2008). These trends have been strongly linked with both genetic and environmental factors, including changes in individual and societal lifestyle such as an increase in tobacco use, excessive alcohol consumption, reduced physical activity and adoption of "Western" diets that are high in salt, refined sugar, and unhealthy fats and oils (Luft, 2001).

Studies have shown that approximately $50 \%$ of essential hypertension (EH) is hereditary (Newton-Cheh et al., 2009). Over the past 10 years, many genetic loci have been found to be associated with hypertension through candidate gene studies. Identification of these susceptible genes is potentially useful to elucidate the complex genetic mechanisms of the disease. Recently, single nucleotide polymorphisms (SNPs) in some candidate genes have been proven to confer susceptibility to the disease in some but not all European and Asian countries (Hong et al., 2010; Liu et al., 2011; Xi et al., 2014). The C677T polymorphism in the methylenetetrahydrofolate reductase (MTHFR) gene has been reported to be associated with hypertension by virtue of its role in catalyzing the formation of 5-methylenetetrahydrofolate, a co-substrate for the conversion of homocysteine to methionine. Association studies have been reported in different populations; however, a great number of subsequent studies have produced contrary results. Studies in Caucasian (Qian et al., 2007), Chinese Han (Liu et al., 2011; Li, 2012), Taichung (China) (Lin et al., 2008), and Guangxi (China) (Yin et al., 2012) populations have revealed evidence of significant association between the C677T polymorphism and $\mathrm{EH}$. Additionally, the significant association between C677T polymorphism and hypertension/ hypertension-in-pregnancy suggests that this polymorphism is an independent risk factor of hypertension (Qian et al., 2007). Consistently, studies in Asian populations (Markan et al., 2007) and Spanish subjects (Rodríguez-Esparragón et al., 2003) on the C677T polymorphism in the MTHFR gene revealed similar results. However, the involvement of the MTHFR C677T polymorphism is not consistent in all populations. No significant association was found between gene variants, including MTHFR C677T, and EH in the South East Queensland region of Australia (Fowdar et al., 2012). Further contrary results were found in a Japanese study that revealed 
that the risk of $\mathrm{EH}$ significantly increased in subjects with the 677CC genotype, whereas the C677T gene polymorphism contributed to lower blood pressure (Nakata et al., 1998). These controversial results have suggested that differences in ethnicity and geographical location could genetically predispose individuals to EH (Hong et al., 2010; Xi et al., 2014).

Investigation on the genetic predisposition of Cameroonians to $\mathrm{EH}$ has not yet been examined. Cameroon is made up of 10 regions, grouped into three main ethnic groups: Bantus (South West, Center, South and Littoral regions), semi-Bantu (North West and West regions) and Fulbe (Adamawa, East, Far North and North regions) (Achidi et al., 2012). Intermarriage between the different ethnic groups is limited by culture, traditional beliefs, and dialect. Identification of markers of hypertension by genotyping in ethnic settings like Cameroon will reveal genes that are markers of hypertension in each ethnic group. Results will have an impactful role on displaying the need to have effective monitoring and surveillance systems, the design of new policies to reduce risk, and the assessment of progress in reducing the prevalence of hypertension - all of which will potentially increase awareness in the treatment and control of hypertension.

\section{MATERIAL AND METHODS}

\section{Study population}

The study group was comprised of 50 normotensive controls and 41 hypertensive subjects between 40 and 70 years of age. All hypertensive subjects were recruited randomly from the diabetic and hypertension center at the Regional Hospital in Buea, South West Region. Hypertensive subjects were defined as having a systolic blood pressure (SBP) of at least 140 $\mathrm{mmHg}$ and a diastolic blood pressure (DBP) of at least $90 \mathrm{mmHg}$. Subjects who were already placed on hypertensive medication were also categorized as hypertensive. All the hypertensive patients were required to be free of secondary hypertension or diabetes mellitus, and to have been diagnosed with hypertension before the age of 70 years. They had a family history of $\mathrm{EH}$ in their parents and/or siblings and were not obese [body mass index (BMI) $<25 \mathrm{~kg} / \mathrm{m}^{2}$ ]. Normotensive controls were recruited randomly from the Buea Municipality. These individuals were never treated with antihypertensive medications, and their SBP was less than $140 \mathrm{mmHg}$ and DBP less than 90 $\mathrm{mmHg}$. They had no family history of hypertension. All of the subjects were unrelated and were native Cameroonians of the Bantu ethnic group of the South West Region. All subjects gave their consent and ethical approval for this study was obtained from the Faculty of Health Science Ethics Committee of the University of Buea.

\section{Collection/measurement of anthropometric and biochemical data}

A structured questionnaire was used for data collection on anthropometric variables (height, weight, and gender), family history, and complications of hypertension. BMI was calculated as weight divided by height squared $\left(\mathrm{kg} / \mathrm{m}^{2}\right)$. Resting blood pressure was measured in the right upper arm of subjects using a CardioChek PA analyzer (USA). Fasting blood sugar (FBS) was measured using the OneTouch UltraSoft lipid profile strip (Hanover, Germany) and analyzer. Serum lipid levels were measured using lipid profile test strips that provided a quantitative measurement of total cholesterol (TC), high-density lipoprotein cholesterol (HDL-C), triglycerides (TG), and lowdensity lipoprotein cholesterol (LDL-C) in blood. 


\section{DNA extraction}

Whole blood from participants was collected by venipuncture in microtainer tubes with EDTA by a trained nurse as described by Kiechle et al. (2010). DNA was extracted from blood using the GenElute Blood Genomic DNA kit (Sigma, Germany) according to manufacturer protocols.

\section{Amplification of the MTHFR genes by polymerase chain reaction (PCR)}

In order to amplify the MTHFR gene, PCR was employed. The PCR was carried out in a $25-\mu \mathrm{L}$ reaction mixture comprised of $0.5 \mu \mathrm{g}$ genomic DNA, $25 \mu \mathrm{M}$ each primer, $10 \mu \mathrm{L}$ deionized water and $12.5 \mu \mathrm{L}$ PCR master mix containing $2.5 \mathrm{mM}$ each dNTP (dATP, dCTP, dGTP, and dTTP), $2.0 \mathrm{mM} \mathrm{MgCl}, 1 X$ Taq buffer and $0.05 \mathrm{U} / \mu \mathrm{L}$ Taq DNA polymerase. Primer sequences used for the amplification of the MTHFR gene were: 5'-TGAAGGAGAAGGTGTCTGCGGGA-3' (forward) and 5'-AGGACGGTGCGGTGAGAGTG-3' (reverse). The predenaturation step was carried out for $3 \mathrm{~min}$ at $94^{\circ} \mathrm{C}$. This was followed by a denaturation step at $94^{\circ} \mathrm{C}$ for $1 \mathrm{~min}$, annealing at $63^{\circ} \mathrm{C}$ for $1 \mathrm{~min}$, and polymerization at $72^{\circ} \mathrm{C}$ for $1 \mathrm{~min}$ with a final extension at $72^{\circ} \mathrm{C}$ for $7 \mathrm{~min}$. Forty PCR amplification cycles were carried out in an Applied Biosystems thermal cycler (Darmstadt, Germany). PCR products were visualized on $2 \%$ agarose gels containing ethidium bromide.

\section{Restriction digestion of MTHFR gene PCR products}

The 25- $\mu \mathrm{L}$ unpurified PCR product was digested with $0.5 \mathrm{U}$ Hinfl, (NEB, USA) restriction enzyme at $37^{\circ} \mathrm{C}$ for $1 \mathrm{~h}$. The digested PCR products were separated on $2 \%$ ethidium bromidestained agarose gels and visualized under UV light.

\section{Statistical analysis}

All the statistical analyses were carried out using the SPSS (Chicago, IL, USA) software version 14.0 for Microsoft Windows. Continuous variables were compared between the groups using the two-tailed Student $t$-test. Allelic frequencies were calculated by the gene-counting method and Hardy-Weinberg equilibrium of genotype distribution was calculated by a chi-squared test. P < 0.05 was considered statistically significant.

\section{RESULTS}

\section{Characteristics of the study population}

Analysis of anthropometric and biochemical data [means \pm standard deviation (SD)] revealed that there were significant differences in age as well as LDL-C, TC and TG levels between hypertensive and normotensive subjects. No significant differences were observed in FBS, BMI, and HDL-C levels (Table 1). Lipid profile dispersion for all subjects showed that serum lipid levels were generally higher in hypertensive than normotensive subjects (Figure 1).

SBP (systolic blood pressure); DBP (diastolic blood pressure); FBS (fasting blood sugar); BMI (body mass index); HDL (high-density lipoprotein); LDL (low-density lipoprotein); TC (total cholesterol); TG (triglyceride). Reference values (RV) for parameters are: $\mathrm{FBS}=70-110 \mathrm{mg} / \mathrm{dL}$; $\mathrm{HDL}-\mathrm{C}=30-70 \mathrm{mg} / \mathrm{dL}$ (men) and 30-85 mg/dL (women); serum LDL-C < $140 \mathrm{mg} / \mathrm{dL}$; serum TC < 
$200 \mathrm{mg} / \mathrm{dL}$; serum TG $<160 \mathrm{mg} / \mathrm{dL}$. Quantitative data were compared using the Student $t$-test. P values in bold indicate statistical significance.

Table 1. Anthropometric and biochemical data of subjects.

\begin{tabular}{l|c|c|c}
\hline \multirow{2}{*}{ Parameters } & Normotensive subjects & Hypertensive patients & P value \\
\cline { 2 - 4 } & (means \pm SD) & (means \pm SD) & \\
\hline Age $($ years) & $52.16 \pm 8.4$ & $56 \pm 9$ & $\mathrm{P}=0.034$ \\
\hline SBP $(\mathrm{mmHg})$ & $129.26 \pm 18.34$ & $151.9 \pm 24.9$ & $\mathrm{P}=0.0001$ \\
\hline DBP $(\mathrm{mmHg})$ & $85.1 \pm 12$ & $96 \pm 16.4$ & $\mathrm{P}=0.002$ \\
\hline FBS $(\mathrm{mg} / \mathrm{dL})$ & $87.84 \pm 9.7$ & $94.2 \pm 72$ & $\mathrm{P}=0.101$ \\
\hline HDL-C $(\mathrm{mg} / \mathrm{dL})$ & $61.52 \pm 29.9$ & $96.9 \pm 181.2$ & $\mathrm{P}=0.172$ \\
\hline LDL-C $(\mathrm{mg} / \mathrm{dL})$ & $81.4 \pm 32.8$ & $180 \pm 126.7$ & $\mathrm{P}=0.0001$ \\
\hline TC $(\mathrm{mg} / \mathrm{dL})$ & $152.02 \pm 40.68$ & $221.8 \pm 45.1$ & $\mathrm{P}=0.012$ \\
\hline TG & $83.66 \pm 48.55$ & $123.1 \pm 67.4$ & $\mathrm{P}=0.001$ \\
\hline BMl $\left(\mathrm{kg} / \mathrm{m}^{2}\right)$ & $29.5 \pm 6.3$ & $36.27 \pm 56.5$ & $\mathrm{P}=0.366$ \\
\hline DHTN $($ years $)$ & & $6.08 \pm 6.8$ & \\
\hline
\end{tabular}

Figure 1. Lipid profile for hypertensive $(\mathrm{HT})$ and control $(\mathrm{C})$ subjects. Serum levels of low-density lipoprotein-cholesterol (LDL-C), total cholesterol (TC), and triglycerides (TG) for each individual are represented as a scatter plot. The mean for each group is shown as a line.

\section{Genotype and allele frequency distribution}

Gel analysis of Hinfl-digested PCR products revealed that all genotypes were represented (Figure 2). The distribution of the three genotypes was in accordance with the Hardy-Weinberg equilibrium both in the normotensive and hypertensive populations. However, the genotype distribution was significantly different between the two groups $\left(\chi^{2}=0.03 ; P=0.038\right)$. The frequency of the $T$ allele was higher in the hypertensive group than in the normotensive group. Contrary to this, the $\mathrm{C}$ allele was higher in the normotensive than in the hypertensive subjects (Table 2; $\chi^{2}=$ $0.029 ; \mathrm{P}=0.022$ ).

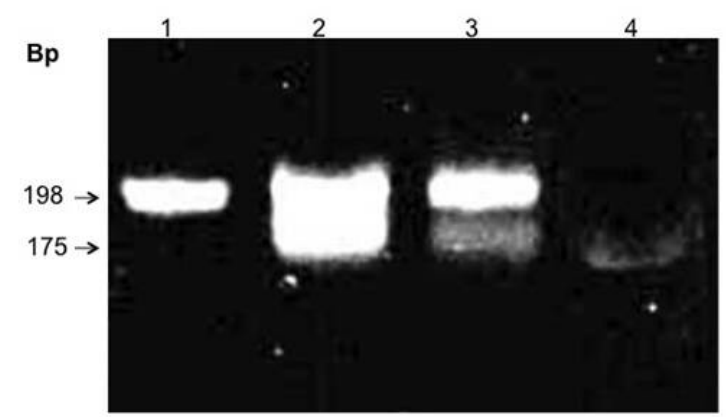

Figure 2. RFLP analysis of the MTHFR C677T polymorphism using Hinfl restriction enzyme. Lane 1 = CC genotype, lanes 2 and 3 = CT genotype, lane $4=$ TT genotype. Band sizes are shown in base pairs (bp).

\section{Allele frequency in hypertensive males and females}

Genotype distribution by gender in both hypertensive and normotensive subjects revealed that while the frequency of the T allele was higher in the hypertensive males than in their normal control counterparts (18:1), the $C$ allele frequency was lower in the hypertensive males than in their 
normal control counterparts (12:33) (Table 3). The same trend was found in females, with the frequency of the $T$ allele higher in hypertensive subjects than in normal controls (34:1) and the frequency of the $\mathrm{C}$ allele lower in hypertensive subjects than in normal controls (18:65) (Table $3)$. Thus, no gender preference in the genotype of this polymorphism was observed $\left(\chi^{2}=1.202\right.$, $P=0.273)$.

Table 2. MTHFR genotype distribution and allele frequencies in normotensive and hypertensive subjects.

\begin{tabular}{l|c|c|c|c|c}
\hline \multirow{2}{*}{} & \multicolumn{3}{|c|}{ Genotype } & \multicolumn{2}{c}{ Allele } \\
\cline { 2 - 6 } & TT & TC & CC & T & 95 \\
\hline $\begin{array}{l}\text { Control } \\
(\mathrm{N}=50)\end{array}$ & 0 & 5 & 45 & $5 \%$ & $95 \%$ \\
\cline { 2 - 6 } $\begin{array}{l}\text { Hypertensive } \\
(\mathrm{N}=41)\end{array}$ & $0 \%$ & $10 \%$ & 3 & 52 & 30 \\
\cline { 2 - 6 } & 14 & 24 & $7.3 \%$ & \multicolumn{2}{c}{$0.022(0.029)$} \\
\hline $\mathrm{P}\left(\chi^{2}\right)$ & $34.1 \%$ & $58.5 \%$ & & $56.6 \%$ \\
\hline
\end{tabular}

Table 3. Genotype and allele distribution with respect to gender.

\begin{tabular}{|c|c|c|c|c|c|c|c|c|}
\hline & & & \multicolumn{3}{|c|}{ Genotype } & \multicolumn{2}{|c|}{ Allele } & \multirow[t]{2}{*}{ Total } \\
\hline & & & TT & TC & $\mathrm{CC}$ & $\mathrm{T}$ & $\mathrm{C}$ & \\
\hline & \multirow{4}{*}{ Male } & \multirow[t]{2}{*}{ Control } & 0 & 1 & 16 & 1 & 33 & 17 \\
\hline & & & $0 \%$ & $5.9 \%$ & $94.1 \%$ & $2.9 \%$ & $97.1 \%$ & $100 \%$ \\
\hline & & \multirow[t]{2}{*}{ Hypertensive } & 4 & 10 & 1 & 18 & 12 & 15 \\
\hline & & & $26.7 \%$ & $66.6 \%$ & $6.7 \%$ & $60 \%$ & $40 \%$ & $100 \%$ \\
\hline & \multirow[t]{4}{*}{ Female } & \multirow[t]{2}{*}{ Control } & 0 & 1 & 32 & 1 & 65 & 33 \\
\hline & & & 0 & $3.0 \%$ & $97.0 \%$ & $1.5 \%$ & $98.5 \%$ & $100 \%$ \\
\hline & & \multirow[t]{2}{*}{ Hypertensive } & 10 & 14 & 2 & 34 & 18 & 26 \\
\hline & & & 38.5 & $53.8 \%$ & $7.7 \%$ & $65.4 \%$ & $34.6 \%$ & $100 \%$ \\
\hline $\mathrm{P}\left(\chi^{2}\right)$ & \multicolumn{8}{|c|}{$\chi^{2}=3.065 ; P=0.216$} \\
\hline
\end{tabular}

To determine the association between genotype and risk factors, all subjects were classified according to genotype and matched with the mean values of each significant risk factor. From 91 subjects, genotype distribution was as follows: 14 TT, 26 CT, and 51 CC. For each risk factor, the statistical value of TT vs TC and CC was determined and only serum LDL-C levels significantly varied with genotype (P value for TT vs TC + CC was 0.02) (Table 4).

Table 4. MTHFR genotypes according to biochemical and anthropometric risk factors in all subjects.

\begin{tabular}{l|c|c|c|c}
\hline Risk factor & $\begin{array}{c}\text { Genotype TT } \\
(\mathrm{N}=14)\end{array}$ & $\begin{array}{c}\text { Genotype CT } \\
(\mathrm{N}=26)\end{array}$ & $\begin{array}{c}\text { Genotype CC } \\
(\mathrm{N}=51)\end{array}$ & $\begin{array}{c}\mathrm{P} \text { value } \\
(\mathrm{TT} \text { vs TC + CC) }\end{array}$ \\
\hline Mean age $($ years $)$ & $51 \pm 0.90$ & $58 \pm 1.56$ & $57 \pm 1.15$ & 0.25 \\
\hline SBP $(\mathrm{mmHg})$ & $142.2 \pm 11.43$ & $142 \pm 12.20$ & $149.26 \pm 16.30$ & 0.62 \\
\hline DBP $(\mathrm{mmHg})$ & $90 \pm 6.90$ & $91 \pm 8.32$ & $92.1 \pm 11$ & 0.34 \\
\hline Serum LDL-C $(\mathrm{mg} / \mathrm{dL})$ & $232.11 \pm 14.54$ & $190.22 \pm 19.60$ & $95.4 \pm 28.60$ & $\mathbf{0 . 0 2}$ \\
\hline Serum TC $(\mathrm{mg} / \mathrm{dL})$ & $183.83 \pm 25.22$ & $151 \pm 31.15$ & $210.02 \pm 41.68$ & 0.26 \\
\hline Serum TG $(\mathrm{mg} / \mathrm{dL})$ & $124.77 \pm 34.38$ & $113.54 \pm 28.55$ & $112.63 \pm 48.59$ & 0.35 \\
\hline
\end{tabular}

The reference values for risk factors are: SBP = $120 \mathrm{mmHg}$; DBP $=80 \mathrm{mmHg}$; serum LDL-C = $140 \mathrm{mg} / \mathrm{dL}$; serum TC = $200 \mathrm{mg} / \mathrm{dL}$; serum TG = $160 \mathrm{mg} / \mathrm{dL}$. All data are reported as means \pm SD. Means were compared using ANOVA. $P$ value in bold indicates statistical significance. 


\section{DISCUSSION}

A number of studies have been conducted to investigate the genetic components of $\mathrm{EH}$. The MTHFR C677T mutation is one of the most common gene polymorphisms. In the present investigation, we examined allele and genotype frequencies between healthy and hypertensive subjects as well as whether a significant association exists between the MTHFR C677T gene polymorphism and clinical data in the Bantu ethnic group of the Buea Municipality in South West Cameroon. The identification of this polymorphism in this subset of the Cameroonian population as a health risk factor will help people who are predisposed to hypertension to make adequate health decisions in order to prevent the disease.

Anthropometric and biochemical factors considered as risk factors were age, LDL-C, TC, and TG since the mean levels of each of these parameters were significantly higher in hypertensive than in normotensive subjects. On the other hand, gender, FBS, HDL-C, and BMI were not observed to be risk factors. These results are comparable to the study of Cai et al. (2014), where significant differences between the two groups were observed for LDL-C, TC and TG but not HDL-C in a Chinese Han population in Xinjiang Shihezi, China. Their results also revealed dependency of EH on FBS but not age. Further, contradictory reports from Chandra et al. (2014) revealed that levels of LDL-C, TC, TG, and HDL-C were comparable in both hypertensive patients and the control group. These results strengthen the fact that risk factors for hypertension are dependent on ethnicity.

The distributions of genotypes were in accordance with the Hardy-Weinberg equilibrium both in the normotensive and hypertensive populations. However, the genotype distribution was significantly different between the two groups $\left(\chi^{2}=0.03, P=0.038\right)$. The frequency of the T allele was higher in the hypertensive group than in the normotensive group while the $\mathrm{C}$ allele was higher in the normotensive group than in the hypertensive group $\left(\chi^{2}=0.022 ; \mathrm{P}=0.029\right.$; Table 2). Our study therefore revealed a strong association between the T allele of the MTHFR C677T polymorphism and hypertension. These results are comparable to those obtained in populations from Spain (Rodríguez-Esparragón et al., 2003), Chinese Han (Liu et al., 2011; Li, 2012), Taichung, China (Lin et al., 2008), and Guangxi, China (Yin et al., 2012). On the contrary, our results are different from those carried out on Chinese Caucasians (Fowdar et al., 2012) and Japanese (Nakata et al., 1998), where the T allele did not predispose subjects to hypertension. Our results did not reveal any gender-related differences with respect to the MTHFR C677T polymorphism and hypertension. These results are contrary to those obtained in Spain where the MTHFR TT genotype could predict the development of EH in males (Rodríguez-Esparragón et al., 2003). Our results confirm the fact that differences in ethnicity and geographical location could genetically predispose individuals to hypertension (Hong et al., 2010; Xi et al., 2014).

We examined an association between genotype and risk factor by determining if there was any significant difference between the frequencies of TT vs TC + CC for each of the parameters considered risk factors. While the difference in genotype frequency was not significant for mean age, SBP, DBP, TC, or TG ( $P>0.05)$, it was significant for LDL-C $(P=0.02)$. These results suggest that the MTHFR C677T polymorphism may predispose individuals to hypertension through an increase in the level of LDL-C.

Considering the genotype and allele frequencies as well as the biochemical parameters obtained, the present results suggest an association between the MTHFR C677T gene polymorphism, LDL-C, and hypertension in the Bantu ethnic group of South West Cameroon. 


\title{
Conflicts of interest
}

The authors declare no conflict of interest.

\section{ACKNOWLEDGMENTS}

\author{
Research supported by the Cameroon Ministry of Higher Education in the form of a \\ research modernization allowance.
}

\section{REFERENCES}

Achidi EA, Apinjoh TO, Anchang-Kimbi JK, Mugri RN, et al. (2012). Severe and uncomplicated falciparum malaria in children from three regions and three ethnic groups in Cameroon: prospective study. Malar. J. 11: 215.http://dx.doi. org/10.1186/1475-2875-11-215

Addo J, Smeeth L and Leon DA (2007). Hypertension in sub-saharan Africa: a systematic review. Hypertension 50: 1012-1018. http://dx.doi.org/10.1161/HYPERTENSIONAHA.107.093336

Bygbjerg IC (2012). Double burden of noncommunicable and infectious diseases in developing countries. Science 337: 14991501.http://dx.doi.org/10.1126/science.1223466

Cai W, Yin L, Yang F, Zhang L, et al. (2014). Association between Hcy levels and the CBS844ins68 and MTHFR C677T polymorphisms with essential hypertension. Biomed. Rep. 2: 861-868.

Chandra S, Narang R, Sreenivas V, Bhatia J, et al. (2014). Association of angiotensin II type 1 receptor (A1166C) gene polymorphism and its increased expression in essential hypertension: a case-control study. PLoS One 9: e101502.http:// dx.doi.org/10.1371/journal.pone.0101502

Fowdar JY, Lason MV, Szvetko AL, Lea RA, et al. (2012). Investigation of homocysteine-pathway-related variants in essential hypertension. Int. J. Hypertens. 2012: 1.http://dx.doi.org/10.1155/2012/190923

Hong KW, Jin HS, Lim JE, Kim S, et al. (2010). Recapitulation of two genomewide association studies on blood pressure and essential hypertension in the Korean population. J. Hum. Genet. 55: 336-341.http://dx.doi.org/10.1038/jhg.2010.31

Kiechle FL, Funk D, Rosser R and Sesok-Pizzini D (2010). So you're going to collect a blood specimen: An introduction to phlebotomy, 13th edn. College of American Pathologists Publications, Northfield.

Li YY (2012). Methylenetetrahydrofolate reductase C677T gene polymorphism and coronary artery disease in a Chinese Han population: a meta-analysis. Metabolism 61: 846-852.http://dx.doi.org/10.1016/j.metabol.2011.10.013

Lin PT, Cheng CH, Wei JC and Huang YC (2008). Low plasma pyridoxal 5\$-phosphate concentration and MTHFR 677C-$>$ T genotypes are associated with increased risk of hypertension. Int. J. Vitam. Nutr. Res. 78: 33-40.http://dx.doi. org/10.1024/0300-9831.78.1.33

Liu C, Li H, Qi Q, Lu L, et al. (2011). Common variants in or near FGF5, CYP17A1 and MTHFR genes are associated with blood pressure and hypertension in Chinese Hans. J. Hypertens. 29: 70-75.http://dx.doi.org/10.1097/HJH.0b013e32833f60ab

Lopez A, Mathers C, Ezzati M, Jamison D, et al. (2006). Measuring the global burden of disease and risk factors, 1990-2001. In: Global burden of disease and risk factors. World Bank, Washington D.C.

Luft FC (2001). Twins in cardiovascular genetic research. Hypertension 37: 350-356.http://dx.doi.org/10.1161/01.HYP.37.2.350

Markan S, Sachdeva M, Sehrawat BS, Kumari S, et al. (2007). MTHFR 677 CT/MTHFR 1298 CC genotypes are associated with increased risk of hypertension in Indians. Mol. Cell. Biochem. 302: 125-131.http://dx.doi.org/10.1007/s11010-007$\underline{9434-5}$

Mensah GA (2008). Epidemiology of stroke and high blood pressure in Africa. Heart 94: 697-705.http://dx.doi.org/10.1136/ hrt.2007.127753

Nakata Y, Katsuya T, Takami S, Sato N, et al. (1998). Methylenetetrahydrofolate reductase gene polymorphism: relation to blood pressure and cerebrovascular disease. Am. J. Hypertens. 11: 1019-1023.http://dx.doi.org/10.1016/S08957061(98)00046-6

Newton-Cheh C, Johnson T, Gateva V, Tobin MD, et al.; Wellcome Trust Case Control Consortium (2009). Genome-wide association study identifies eight loci associated with blood pressure. Nat. Genet. 41: 666-676.http://dx.doi.org/10.1038/ ng.361

Qian X, Lu Z, Tan M, Liu H, et al. (2007). A meta-analysis of association between C677T polymorphism in the methylenetetrahydrofolate reductase gene and hypertension. Eur. J. Hum. Genet. 15: 1239-1245.http://dx.doi. org/10.1038/sj.ejhg.5201914 
Rodríguez-Esparragón F, Hernández-Perera O, Rodríguez-Pérez JC, Anábitarte A, et al. (2003). The effect of methylenetetrahydrofolate reductase C677T common variant on hypertensive risk is not solely explained by increased plasma homocysteine values. Clin. Exp. Hypertens. 25: 209-220.http://dx.doi.org/10.1081/CEH-120020391

Tchoumi JC and Butera G (2013). Profile of cardiac disease in Cameroon and impact on health care services. Cardiovasc. Diagn. Ther. 3: 236-243.

Walker RW, McLarty DG, Kitange HM, Whiting D, et al. (2000). Stroke mortality in urban and rural Tanzania. Adult Morbidity and Mortality Project. Lancet 355: 1684-1687.http://dx.doi.org/10.1016/S0140-6736(00)02240-6

Whelton PK, He J, Appel LJ, Cutler JA, et al.; National High Blood Pressure Education Program Coordinating Committee (2002). Primary prevention of hypertension: clinical and public health advisory from The National High Blood Pressure Education Program. JAMA 288: 1882-1888.http://dx.doi.org/10.1001/jama.288.15.1882

Xi B, Shen Y, Zhao X, Chandak GR, et al. (2014). Association of common variants in/near six genes (ATP2B1, CSK, MTHFR, CYP17A1, STK39 and FGF5) with blood pressure/hypertension risk in Chinese children. J. Hum. Hypertens. 28: 32-36. http://dx.doi.org/10.1038/jhh.2013.50

Yin RX, Wu JZ, Liu WY, Wu DF, et al. (2012). Association of several lipid-related gene polymorphisms and blood pressure variation in the Bai Ku Yao population. Am. J. Hypertens. 25: 927-936.http://dx.doi.org/10.1038/ajh.2012.55 